\title{
Pharmacotherapics Advice in Guidelines for COVID-19
}

\author{
Zhang-Ren Chen ${ }^{\dagger}$, Ying Zhou ${ }^{\dagger}$, Jin Liu, Hong-Wei Peng, Jian Zhou, Hai-Li Zhong, \\ Li-Li Liu, Ming-Fang Lai, Xiao-Hua Wei and Jin-Hua Wen*
}

Department of Pharmacy, The First Affiliated Hospital of Nanchang University, Nanchang, China

\section{OPEN ACCESS}

Edited by:

Irfan Rahman,

University of Rochester, United States

Reviewed by:

John F. Alcorn,

Children's Hospital of Pittsburgh,

School of Medicine, University of

Pittsburgh, United States

Vaidehi Jatin Thanawala,

Vapogenix Inc, United States

${ }^{*}$ Correspondence:

Jin-Hua Wen

jinhuawen_ncu@yeah.net

${ }^{\dagger}$ These authors have contributed equally to this work and share first authorship

Specialty section: This article was submitted to Respiratory Pharmacology, a section of the journal

Frontiers in Pharmacology

Received: 17 March 2020 Accepted: 11 June 2020

Published: 24 June 2020

Citation:

Chen Z-R, Zhou Y, Liu J, Peng H-W, Zhou J, Zhong H-L, Liu L-L, Lai M-F,

Wei X-H and Wen J-H (2020)

Pharmacotherapics Advice in

Guidelines for COVID-19.

Front. Pharmacol. 11:950.

doi: 10.3389/fphar.2020.00950
Since December 2019 to May 2020, coronavirus disease 2019 (COVID-19) has infected over 6 million people worldwide. Due to its sudden and rapid outbreak, effective treatment for COVID-19 is scarce. Based on national clinical trials of novel treatments, China, Italy, Germany, and other countries and organizations have published multiple guidelines for COVID-19 and advised many medicines, such as chloroquine and tocilizumab. In this paper, we summarize the pharmacotherapy for COVID-19 according to those guidelines, highlight updates of the pharmacotherapy guidelines, and review the efficacy and safety of the indicated anti-COVID-19 drugs.

Keywords: COVID-19, pneumonia, guideline, pharmacotherapy, SARS-CoV-2

\section{INTRODUCTION}

SARS-CoV-2 (previously termed 2019 novel coronavirus, 2019-nCoV), a virus that causes COVID19, likely initially transmitted from bat to human (Gorbalenya et al., 2020), infected over 6 million people worldwide from its outbreak in December 2019 to May 2020 (China CDC, 2020; WHO, 2020a). Due to the relatively high basic reproduction number $\left(\mathrm{R}_{0}\right)$ of the 2019-nCoV virus (Liu et al., 2020), COVID-19 spread rapidly and has already become a pandemic. The World Health Organization (WHO) has declared a Public Health Emergency of International Concern (PHEIC) for COVID-19 (WHO, 2020b) and has announced that COVID-19 is a pandemic (National Public Radio, 2020). Controlling the transmission and treating the infected cases is of great urgency.

To develop treatments for COVID-19, many marketed drugs have been re-purposed for usage in the clinic. China, Italy, Germany, the ATS (American Thoracic Society), the SSC (Surviving Sepsis Campaign), the NIH (National Institutes of Health), the IDSA (Infectious Diseases Society of America), and the FDA (Food and Drug Administration) released guidelines and recommended several medicines for the treatment of COVID-19 (Table 1). Since January 16, 2020, China's government has published seven editions of guidelines for the diagnosis and treatment of 2019 novel coronavirus (2019-nCoV)-infected pneumonia (hereinafter referred to as the Chinese Guidelines, Table 2, Figure 1) (The national commission of the people's republic of China, 2020a; The national commission of the people's republic of China, 2020b; The national commission of the people's republic of China, 2020c; The national commission of the people's republic of China, 2020d; The national commission of the people's republic of China, 2020e; The national commission of the people's republic of China, 2020f; The national commission of the people's republic of China, 2020g) and two editions of guidelines for the diagnosis and treatment of serious and critical 2019 novel coronavirus (2019-nCoV)-infected pneumonia (The national commission of the people's republic of China, 2020h; The national commission of the people's republic of China, 2020i). To date, there is 
TABLE 1 | The pharmacotherapies advised by official guidelines for COVID-19

\begin{tabular}{|c|c|c|c|c|c|c|c|c|c|c|c|c|}
\hline $\begin{array}{l}\text { Country/ } \\
\text { Organization }\end{array}$ & IFN & Ribavirin & Arbidol & Anti-HIV drugs & $\mathrm{HCQ} / \mathrm{CQ}$ & Azithromycin & Remdesivir & Corticosteroids & Tocilizumab & Other Drugs & Update time & References \\
\hline $\begin{array}{l}\text { China (7th } \\
\text { edition) }\end{array}$ & Yes & Yes & Yes & Yes $(L / r)$ & Yes & & & $\begin{array}{l}\text { Severe and } \\
\text { critical cases }\end{array}$ & Yes & (Detailed in Table 2) & 2020.03.04 & $\begin{array}{l}\text { (The National } \\
\text { Commission of the } \\
\text { People's Republic of } \\
\text { China, 2020i) }\end{array}$ \\
\hline German & & & & $\begin{array}{l}\text { Compassionate } \\
\text { use }(\llcorner/ r)\end{array}$ & $\begin{array}{l}\text { Compassionate } \\
\text { use }\end{array}$ & & $\begin{array}{l}\text { Compassionate } \\
\text { use }\end{array}$ & & & $\begin{array}{l}\text { Camostat } \\
\text { (compassionate } \\
\text { use) }\end{array}$ & 2020.04 .14 & (Kluge et al., 2020) \\
\hline Italy 2.0 & & & & $\begin{array}{l}\text { Yes }(L / r, \\
\text { Darunavir, } \\
\text { Darunavir/ } \\
\text { cobicistat) }\end{array}$ & Yes & & Yes & $\begin{array}{l}\text { Only patients } \\
\text { with ARDS }\end{array}$ & Yes & & 2020.03 .13 & $\begin{array}{l}\text { (Italian Society of } \\
\text { Infectious and } \\
\text { Tropical Diseases } \\
\text { SECTION, 2020) }\end{array}$ \\
\hline ATS & & & & No suggestion & $\begin{array}{l}\text { Conditional (on } \\
\text { a case-by-case } \\
\text { basis) }\end{array}$ & & No suggestion & No suggestion & $\begin{array}{l}\text { No } \\
\text { suggestion }\end{array}$ & & 2020.04 .03 & (Wilson et al., 2020) \\
\hline $\mathrm{NIH}$ & $\begin{array}{l}\text { Only in } \\
\text { clinical } \\
\text { trial }\end{array}$ & & & $\begin{array}{l}\text { Only in clinical } \\
\text { trial }\end{array}$ & $\begin{array}{l}\text { Only in clinical } \\
\text { trial }\end{array}$ & $\begin{array}{l}\text { Only in clinical } \\
\text { trial }\end{array}$ & $\begin{array}{l}\text { For severe } \\
\text { cases; Not for } \\
\text { mild or } \\
\text { moderate cases }\end{array}$ & $\begin{array}{l}\text { Only patients } \\
\text { with refractory } \\
\text { shock }\end{array}$ & & $\begin{array}{l}\text { Janus kinase } \\
\text { inhibitors (e.g., } \\
\text { baricitinib, in clinical } \\
\text { trial) }\end{array}$ & 2020.05 .12 & $(\mathrm{NIH}, 2020)$ \\
\hline IDSA & $\begin{array}{l}\text { Only in } \\
\text { clinical } \\
\text { trial }\end{array}$ & $\begin{array}{l}\text { Only in } \\
\text { clinical } \\
\text { trial }\end{array}$ & $\begin{array}{l}\text { Only in } \\
\text { clinical } \\
\text { trial }\end{array}$ & $\begin{array}{l}\text { Only in clinical } \\
\text { trial }\end{array}$ & $\begin{array}{l}\text { Only in clinical } \\
\text { trial }\end{array}$ & $\begin{array}{l}\text { Only in clinical } \\
\text { trial }\end{array}$ & $\begin{array}{l}\text { Only in clinical } \\
\text { trial }\end{array}$ & $\begin{array}{l}\text { Only patients } \\
\text { with ARDS }\end{array}$ & $\begin{array}{l}\text { Only in } \\
\text { clinical trial }\end{array}$ & & 2020.04 .21 & (Bhimraj et al., 2020) \\
\hline FDA & & & & & $\begin{array}{l}\text { EUA } \\
\text { (both HQ \& CQ) }\end{array}$ & & EUA & & & & 2020.05 .16 & $(F D A, 2020)$ \\
\hline SSC & & & & & & & & $\begin{array}{l}\text { Only patients } \\
\text { with ARDS }\end{array}$ & & $\begin{array}{l}\text { Antimicrobials/ } \\
\text { antibacterial agents, } \\
\text { acetaminophen/ } \\
\text { paracetamol }\end{array}$ & 2020.03 .28 & $\begin{array}{l}\text { (Alhazzani et al., } \\
\text { 2020) }\end{array}$ \\
\hline
\end{tabular}

Key: ATS, American Thoracic Society; SSC, Surviving Sepsis Campaign; NIH, National Institutes of Health; IDSA, Infectious Diseases Society of America; FDA, Food and Drug Administration; ARDS, Acute Respiratory Distress Syndrome; IFN, interferon; EUA, emergency use authorization; HCQ, hydroxychloroquine; $C Q$, chloroquine; L/r, Lopinavir/ritonavir. 
TABLE 2 | Updates of the pharmacotherapy recommendations of the Chinese Guidelines for COVID-19 (1st to 7th edition).

\begin{tabular}{|c|c|c|c|c|c|c|c|}
\hline Edition & Updated Date & \multicolumn{4}{|c|}{ General treatments } & $\begin{array}{l}\text { Treatments for Severe and } \\
\text { Critical cases }\end{array}$ & Major Changes \\
\hline 2nd & $2020 / 1 / 21$ & $\begin{array}{l}\text { (Same as the } \\
\text { previous } \\
\text { edition) }\end{array}$ & $\begin{array}{l}\text { (Same as the previous } \\
\text { edition) }\end{array}$ & $\begin{array}{l}\text { (Same as the } \\
\text { previous edition) }\end{array}$ & $\begin{array}{l}\text { (Same as } \\
\text { the } \\
\text { previous } \\
\text { edition) }\end{array}$ & - & - \\
\hline 4th & 2020/1/27 & $\begin{array}{l}\text { (Same as the } \\
\text { previous } \\
\text { edition) }\end{array}$ & $\begin{array}{l}\text { (Same as the previous } \\
\text { edition) }\end{array}$ & - & - & $\begin{array}{l}\text { Glucocorticoids: dose for a short } \\
\text { period of time ( } 3 \text { to } 5 \text { days); }<1-2 \\
\text { ml/kg/day methylprednisolone; } \\
\text { Xuebijing: } 100 \mathrm{~mL} / \mathrm{d} \text { iv injection, } \\
\text { tid; } \\
\text { Intestinal microecological } \\
\text { regulators; } \\
\text { Convalescent plasma therapy }\end{array}$ & $\begin{array}{l}\text { Glucocorticoids were } \\
\text { removed from general } \\
\text { treatments and } \\
\text { recommended for } \\
\text { serious and critical } \\
\text { cases only }\end{array}$ \\
\hline 5th & 2020/2/8 & $\begin{array}{l}\text { Alpha- } \\
\text { interferon: } \\
5 \text { million } U \\
\text { inhalation tid; } \\
\text { Lopinavir/ } \\
\text { ritonavir: } \\
\text { Lopinavir } 400 \\
\text { mg-ritonavir } \\
100 \text { mg orally } \\
\text { tid. } \\
\text { Ribavirin: } \\
\text { 500mg, bid/ } \\
\text { tid ivgtt. }\end{array}$ & $\begin{array}{l}\text { (Same as the previous } \\
\text { edition) }\end{array}$ & - & - & (Same as the previous edition) & $\begin{array}{l}\text { Ribavirin and } \\
\text { convalescent plasma } \\
\text { therapy }\end{array}$ \\
\hline 6th & 2020/2/19 & $\begin{array}{l}\text { Alpha- } \\
\text { interferon: } \\
5 \text { million } U \\
\text { inhalation tid; } \\
\text { Lopinavir/ } \\
\text { ritonavir: } \\
\text { Lopinavir } 400 \\
\text { mg-ritonavir } \\
100 \text { mg orally } \\
\text { tid. } \\
\text { Ribavirin: } \\
500 \text { mg, bid/ } \\
\text { tid ivgtt. } \\
\text { In } \\
\text { combination } \\
\text { with interferon } \\
\text { and lopinavir/ } \\
\text { ritonavir; } \leq 10 \\
\text { days; } \\
\text { Chloroquine: } \\
500 \text { mg orally } \\
\text { bid, } \leq 10\end{array}$ & $\begin{array}{l}\text { (Same as the previous } \\
\text { edition) }\end{array}$ & - & - & (Same as the previous edition) & $\begin{array}{l}\text { Chloroquine } \\
\text { phosphate and abidol }\end{array}$ \\
\hline
\end{tabular}


TABLE 2 | Continued

\begin{tabular}{|c|c|c|c|c|c|c|c|}
\hline Edition & Updated Date & \multicolumn{4}{|c|}{ General treatments } & $\begin{array}{c}\text { Treatments for Severe and } \\
\text { Critical cases }\end{array}$ & Major Changes \\
\hline
\end{tabular}

still no approved specific antiviral drug for COVID-19, and providing supportive care to help relieve symptoms is the most vital strategy for COVID-19 treatment. In this article, we summarize the pharmacotherapy guidelines for COVID-19, highlight the updates to the pharmacotherapy guidelines, and reviewed the efficacy and safety of the anti-COVID-19 drugs recommended.

\section{ANTIVIRAL DRUGS}

The majority of anti-SARS-CoV-2 virus drugs are adopted from the treatment of severe acute respiratory syndrome (SARS) or Middle East respiratory syndrome (MERS): alpha-interferon, lopinavir/ritonavir, and ribavirin. Besides, novel antiviral drugs have also been applied in the clinic, such as chloroquine. Considering the safety and toxicity of those antiviral drugs, the combination of three or more antiviral drugs is not recommended. Most antiviral treatments still lack high-level evidence to support antiviral efficacy. Clinicians should balance the benefits and risks of such drugs before medication.

\section{Remdesivir}

Remdesivir, a nucleoside analog, inhibits RNA replicase polyprotein 1ab (Agostini et al., 2018). It was originally developed for the treatment of the Ebola virus (Warren et al., 2016). Remdesivir has a superior anti-MERS activity compared to lopinavir and ritonavir in vitro and in vivo (Sheahan et al., 2020) and displayed anti-SARS-CoV-2 ability in vitro (Wang $M$. et al., 2020). The first COVID-19 case in the USA used remdesivir, and clinical condition improved from the 2 nd day of remdesivir medication (Holshue et al., 2020). It has been assessed in RCTs in both China and the USA (NIH, 2020).
However, it showed different results in China and the USA. Remdesivir was not associated with statistically significant clinical benefits or adverse events for 237 adult patients admitted to hospital for severe COVID-19 in the RCT enrolled in China (Wang Y. et al., 2020). In the USA, compassionate use of remdesivir displayed clinical improvement in 36 of 53 hospitalized severe COVID-19 patients (Grein et al., 2020) and 14 of 17 patients in the infectious disease ward (Antinori et al., 2020). In an RCT with 1063 patients enrolled in the USA, remdesivir was superior to placebo in shortening the time to recovery and evidence of lower respiratory tract infection; also, an ethnic difference was observed: remdesivir is effective among white patients and is not significantly effective among black and Asian patients (Beigel et al., 2020). The guideline from Italy recommended remdesivir (Italian Society of Infectious and Tropical Diseases SECTION, 2020), and the FDA approved emergency use authorization (EUA) of remdesivir for the treatment of COVID-19 (FDA, 2020). In short, remdesivir is helpful but not a wonder drug for COVID-19 patients (Mahase, 2020).

\section{Favipiravir}

Favipiravir is a modified pyrazine analog and was initially approved for therapeutic use in resistant cases of influenza. It targets RNA-dependent RNA polymerase (RdRp) enzymes and inhibits the transcription and replication of viral genomes (Furuta et al., 2017). Cai et al. found that favipiravir showed significant improvement in chest imaging compared with lopinavir/ritonavir for the treatment of COVID-19 (35 vs. 45 patients). Chen et al. found the favipiravir did not significantly improve the clinical recovery rate at Day 7 compared to arbidol but significantly improved the latency to relief for pyrexia and cough in a 120 vs. 120 patient trial (Chen et al., 2020). However, 


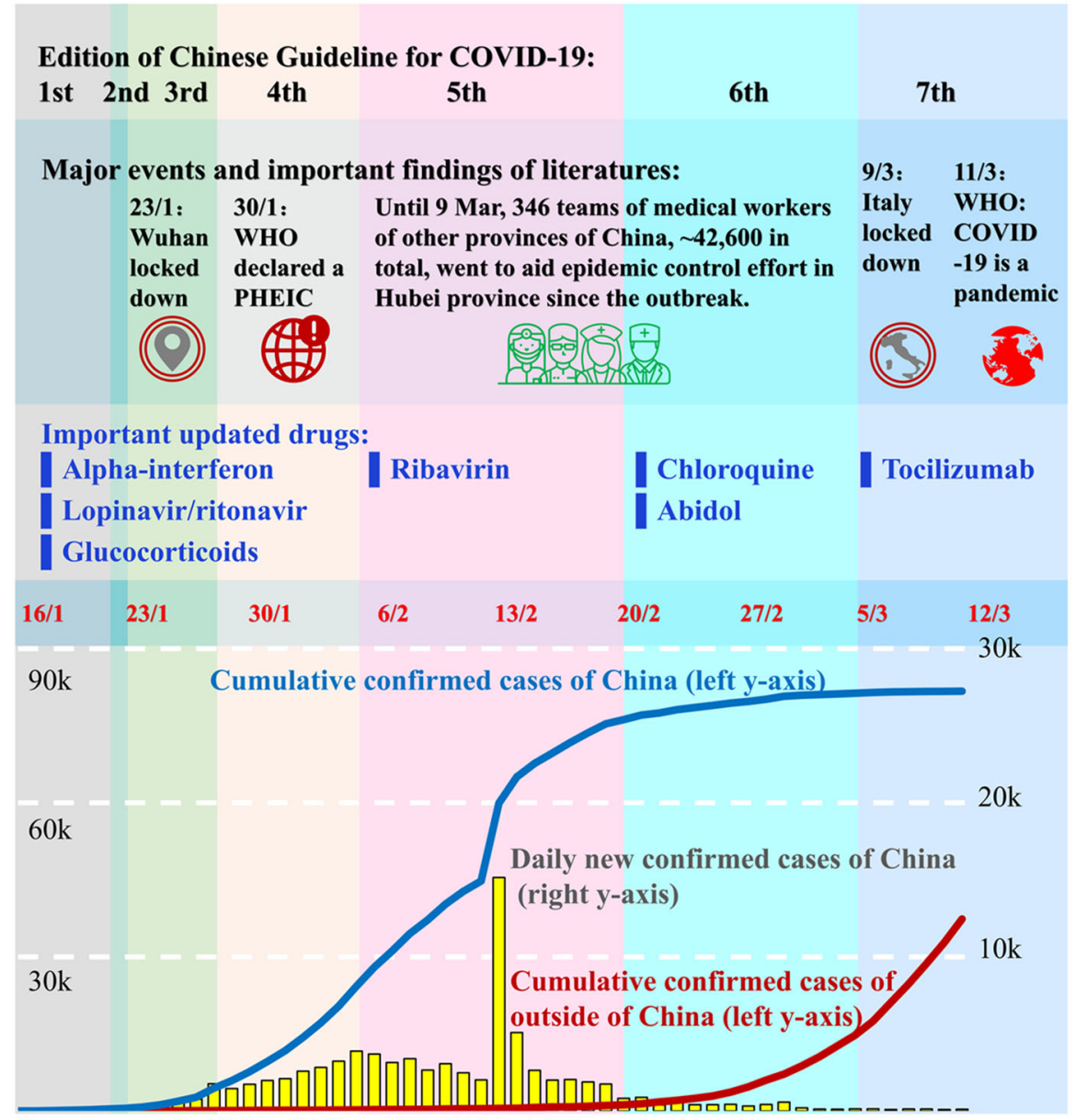

Data resources: China CDC and World Health Organization

FIGURE 1 | Timeline of the publication of the Chinese Guidelines for COVID-19. Since the outbreak of COVID-19 in December 2019, the governments of China and other countries and the World Health Organization (WHO) have taken actions to stop the transmission of the SARS-CoV-2 virus and to treat the infected patients. China's government published seven editions of guidelines for the diagnosis and treatment of COVID-19 from 16 February to 4 March. Those guidelines advised a number of novel drugs for the treatment of COVID-19. Red numbers in the middle are dates. The blue line and red line represent the cumulative confirmed COVID19 cases in China and outside of China, respectively, and correspond to the left y-axis. The yellow bars represent the daily new confirmed cases in China and correspond to the right y-axis. Each colored column presents a corresponding edition of the Chinese Guidelines. The position of drugs in the 3rd row corresponds to the edition in which the drugs were recommended for the first time.

Lou et al. did not observe clinical improvement with favipiravir treatment for COVID-19 patients (Lou et al., 2020). There is still a lack of sufficient evidence to support the clinical anti-COVID19 effects of favipiravir.

\section{Chloroquine and Hydroxychloroquine}

Chloroquine and hydroxychloroquine are canonical quinoline antiparasitic drugs, indicated to treat infections of malaria and also used off-label for the treatment of rheumatic diseases and lupus erythematosus. Besides, Andrea Savarino et al. demonstrated the potential therapeutic benefits of chloroquine in viral diseases (Te et al., 2007), including SARS (Savarino et al., 2003). Thus, it has been re-purposed for the prophylaxis and treatment of Zika virus infection (Li et al., 2017). Wang et al. reported that chloroquine effectively inhibits SARS-CoV-2 infection by increasing endosomal $\mathrm{pH}$ and interfering with the glycosylation of cellular ACE2 receptors (Wang M. et al., 2020). The blood concentration of chloroquine can reach the $\mathrm{EC}_{90}$ value of anti-SARS-CoV-2 with regular dosing for rheumatoid arthritis (Wang M. et al., 2020). In several clinical trials, chloroquine has been proved to inhibit the SARS-CoV-2 virus in vivo (Gao et al., 2020). Therefore, it was included in the Chinese Guidelines for the first time in the 6th edition. Concerning the toxicity of chloroquine, the dose recommended by the Chinese Guidelines was updated in the 7th edition (Riou et al., 1988). Also, an expert consensus statement from Shanghai recommended hydroxychloroquine instead of chloroquine (Cutler et al., 1988; Shanghai Clinical Treatment Expert Group for corona virus disease 2019, 2020). The Italian guidelines recommended chloroquine and hydroxychloroquine (when chloroquine is not 
available) (Italian Society of Infectious and Tropical Diseases SECTION, 2020). The FDA approved the EUA of chloroquine and hydroxychloroquine for the treatment of COVID-19 (FDA, 2020). However, there is still controversy about the effect and safety of chloroquine and hydroxychloroquine. Mehra and colleagues have not found a benefit of hydroxychloroquine or chloroquine, when used alone or with a macrolide, for inhospital outcomes for COVID-19(N=96 032) (Mehra et al., 2020). In an observational study with 1446 hospitalized patients, hydroxychloroquine administration was not associated with either a greatly lowered or an increased risk of the composite endpoint of intubation or death (Tang et al., 2020). The American College of Physicians suggested that clinicians should not use chloroquine or hydroxychloroquine alone or in combination with azithromycin as a treatment of patients with COVID-19 due to the known harms and there being no available evidence of benefits in patients with COVID19 (Qaseem et al., 2020).

\section{Abidol \\ Abidol, also called umifenovir, is a broad-spectrum antiviral drug developed by a Russian pharmaceutical company and approved for marketing in Russia and China (Brooks et al., 2012). It was licensed for the prophylaxis and treatment of influenza and other respiratory viral infections (Brooks et al., 2012). Its mechanisms of antiviral action including interactions with certain amino acid residues to form a hydrophobic aromatic stacking structure and interactions with aromatic residues of the viral glycoproteins involved in fusion and cellular recognition (Kadam and Wilson, 2017; Zeng et al., 2017). Its antiviral ability in the treatment of various virus infections, including SARS (Khamitov et al., 2008) and Ebola virus (Hulseberg et al., 2019), has been studied and proved. Some studies have observed anti- COVID-19 potential in vitro and in clinic (Wang Z. et al., 2020). Chinese Guidelines recommended abidol for anti-COVID-19 treatment from the 6 th edition. A clinical trial from Shanghai did not find any effects of lopinavir/ritonavir and abidol in terms of relieving symptoms or accelerating viral clearance (Jun et al., 2020). A retrospective study showed that abidol might not improve the prognosis or accelerate SARS-CoV-2 clearance in non-ICU patients (Lian et al., 2020).}

\section{Anti-Human Immunodeficiency Virus (HIV) Drugs (Lopinavir/Ritonavir and Darunavir/ Cobicistat)}

Anti-HIV combination antiviral drugs, mainly lopinavir/ ritonavir and darunavir/cobicistat, have been re-purposed as anti-SARS-CoV-2 agents. Both lopinavir and darunavir are inhibitors of the 3CLpro protease of coronavirus, a key protein that cleaves the large replicase polyproteins during viral replication. Ritonavir increases the bioavailability of lopinavir by cytochrome P450 isoenzyme 3A4 (CYP3A4) (Mangum and Graham, 2001), and cobicistat is a more selective cytochrome P450 3A inhibitor than ritonavir without enzyme-inducing properties (Kakuda et al., 2015). Lopinavir/ritonavir has shown anti-coronavirus activity in vitro, in animal model, and in non- randomized trials (Chan et al., 2003; Chu et al., 2004; Chan et al., 2015; Zumla et al., 2016). For COVID-19, lopinavir/ritonavir has been recommended by Chinese Guidelines since the first edition and is also recommended in the guidelines of Italy; the German, ATS, NIH, SSC, and IDSA guidelines do not recommend it (Table 1). It has also been applied for anti-COVID-19 treatment in South Korea (Lim et al., 2020) and Thailand. However, there is still controversy about its efficacy and safety (Jun et al., 2020; Kim, 2020). Cao et al. did not observe any benefit with lopinavirritonavir treatment in 199 hospitalized adult patients with severe COVID-19 (Cao et al., 2020), and Cheng et al. found that lopinavir/ritonavir did not shorten the duration of SARS CoV2 shedding (Cheng et al., 2020). Lopinavir/ritonavir can induce liver damage when treating COVID-19 (Fan et al., 2020). Considering the toxicity of lopinavir/ritonavir, Chinese Guidelines have warned that its adverse reactions should be considered carefully since the 5 th edition and have stated that the treatment should last less than 10 days since the 6th edition; the Italian guidelines recommend both lopinavir/ritonavir and darunavir/cobicistat (Italian Society of Infectious and Tropical Diseases SECTION, 2020). However, according to the case report of Riva et al., darunavir does not prevent SARS-CoV-2 infection in HIV patients (Riva et al., 2020). The triple combination of interferon- $\beta-1 b$, lopinavir/ritonavir, and ribavirin was found to be safe and superior to lopinavir/ritonavir alone in alleviating symptoms and shortening the duration of viral shedding and hospital stay in patients with mild to moderate COVID-19 (Hung et al., 2020).

\section{Interferons (IFN)}

Interferons are broad-spectrum antiviral drugs that regulate the immune system and inhibit the replication of the virus. IFN- $\alpha$ has been applied for the treatment of coronavirus diseases previously, such as for the treatment of SARS (Haagmans et al., 2004) and MERS (Al Ghamdi et al., 2016). IFN- $\alpha$ has been recommended as an anti-SARS-CoV-2 virus drug in the Chinese Guidelines since the first edition. Besides, the expert consensus statement from Shanghai recommended IFN- $\kappa$ rather than IFN- $\alpha$ (Shanghai Clinical Treatment Expert Group for Coronavirus Disease 2019, 2020). A Hong Kong group used IFN- $\beta 1$ b (Hung et al., 2020), and some groups suggested that IFN- $\lambda$ might be helpful for anti-SARS-CoV-2 treatment (Andreakos and Tsiodras, 2020; Prokunina-Olsson et al., 2020).

\section{Ribavirin}

Ribavirin is a prodrug and guanosine analog. It was metabolized into active metabolites, the deribosylated base, and its 5'phosphate derivatives, by host cell enzymes after absorption (Wu et al., 2003). The mechanisms of the antiviral effect of ribavirin including 1) inhibiting the shift from Th2 to Th1 immune response, 2) inhibiting host inosine monophosphate dehydrogenase (IMPDH) and causing a decrease in GTP, 3) directly inhibiting the replication of the virus, and 4) inhibiting the mutagenesis of virus (Te et al., 2007). Its triple combination with interferon- $\beta-1 b$ and lopinavir/ritonavir might be more helpful for anti-COVID-19 treatment compared to lopinavir/ ritonavir alone (Hung et al., 2020). 


\section{Transmembrane Protease, Serine 2 (TMPRSS2) Inhibitors}

The host cell entry of SARS-CoV-2 depends on the ACE2 receptor and protease TMPRSS2. Hoffmann et al. demonstrated that TMPRSS2 inhibitors may block the entry of the virus and that a marketed drug, camostat, might be a potential antiviral treatment for COVID-19 (Hoffmann et al., 2020). German guidelines mentioned the compassionate use of camostat (Kluge et al., 2020).

\section{ANTIBACTERIAL DRUGS}

Both Chinese and German guidelines recommended that blind or inappropriate use of antibacterial drugs, especially the combination of broad-spectrum antibacterial drugs, should be avoided in the clinic (The national commission of the people's republic of China, 2020g). Enhancement of bacteriological surveillance should be performed, and appropriate antibacterial drugs should be given promptly when secondary bacterial infection occurs (Jin et al., 2020).

\section{GLUCOCORTICOIDS}

Glucocorticoids are commonly used for the treatment of SARS owing to their anti-inflammatory and immunosuppressive effects (Loutfy et al., 2003). Since glucocorticoids induce severe sequelae, such as osteonecrosis of the femoral head (Griffith et al., 2005) and mental disorder (Hong et al., 2009), and decelerate the clearance of virus, glucocorticoids were removed from the Chinese Guidelines and not recommended for treatment of mild COVID-19 patients from the 4th edition onwards. For serious and critical patients with progressive deterioration of the oxygenation index, rapid progression as shown in imaging, and excessive activation of the body's inflammatory response or patients with acute respiratory distress syndrome (ARDS), short-term use of glucocorticoids is recommended by the Chinese, Italian, IDSA, and SSC guidelines.

\section{TOCILIZUMAB}

Tocilizumab is a recombinant, humanized, anti-IL-6 receptor monoclonal antagonist (antibody). It is approved for the treatment of cytokine release syndrome (CRS), active rheumatoid arthritis (RA), giant cell arteritis (GCA), active polyarticular juvenile idiopathic arthritis (PJIA), and active systemic juvenile idiopathic arthritis (SJIA) (FDA) (FDA ACTEMRA, 2020). It has a significant therapeutic effect on life-threatening cytokine release (Le et al., 2018). The 7th edition of the Chinese Guidelines recommended tocilizumab as an immunotherapy for patients with extensive lung lesions or severely ill patients who have elevated IL-6 levels. Allergic reactions should be considered. $\mathrm{Xu}$ et al. observed that tocilizumab improved the clinical outcome immediately in severe and critical COVID-19 patients and that it was an effective treatment to reduce mortality (Xu X. et al., 2020). A systematic review showed benefits from tocilizumab to COVID19 (Alzghari and Acuña, 2020).

\section{IMMUNOMODULATORY DRUGS AND INTESTINAL MICROECOLOGICAL PREPARATIONS}

Due to the immune deficiency of some severe patients, it is necessary to strengthen their immune capability. The 2 nd edition of the Chinese Guidelines recommended Thymosin alpha-1 as an immunomodulatory drug (Du et al., 2018) for severe patients with low lymphocyte counts and serious and critical cases with low cellular immunity (The national commission of the people's republic of China, 2020i). Intravenous immunoglobulin gamma (IVIg), a plasma-made mixture of IgG1 and other antibodies (Baerenwaldt et al., 2010), was recommended for severely ill patients, especially children (The national commission of the people's republic of China, 2020i). Intestinal microecological regulators were recommended for maintaining the intestinal microecological balance and preventing secondary bacterial infections (Hidalgo-Cantabrana et al., 2017; The national commission of the people's republic of China, 2020g; The national commission of the people's republic of China, 2020h).

\section{TRADITIONAL CHINESE MEDICINES (TCM)}

The Chinese Guidelines have recommended a set of TCM in a single section since the 3rd edition. Those recommended drugs include Jinhua Qinggan Granules, Lianhua Qingwen Capsule (Mingxing Huang et al., 2020), Shufeng Jiedu Capsule, and other mentioned herbal drugs (Jin et al., 2020) and can be complementary and alternative medicines for mild COVID-19 patients. For serious and critical COVID-19 cases, some traditional Chinese patent medicines are recommended: 1) for viral infection or mild bacterial co-infection: Xiyanping injection, Duning injection, or Tanreqing injection; 2) for high fever with disturbance of consciousness: Xingnaojing injection; 3) for systemic inflammatory response syndrome or/and multiple organ failure: Xuebijing injection. 4) immunosuppression: Shenmai injection or Shengmai injection (The national commission of the people's republic of China, 2020g; The national commission of the people's republic of China, 2020h).

\section{CONCLUSION}

To date, there is still no effective drug to cure COVID-19. Moreover, COVID-19 is still a pandemic as of May 2020, and it will probably become a periodic epidemic. The development of anti-COVID-19 drugs is one of the most important tasks to be done. However, the duration of new drug discovery and development usually last years or even decades. The repurposed use and re-discovery of marketed drugs has become an expressway for anti-COVID-19 drug development. 
When COVID-19 broke out in China, clinicians and researchers lacked knowledge of SARS-CoV-2 and COVID-19. At that time, saving lives was the most important thing to be considered. Many un-approved treatments were therefore tested in the clinic based on the experience of SARS and in vitro studies. As the evidence grew, many drugs were not proved to be effective treatments for COVID-19. Also, chloroquine lopinavir/ritonavir and other drugs have been reported to have toxic effects. This is why there have been seven editions of the Chinese Guidelines. When COVID-19 broke out in Europe and American in the second wave, clinicians had already gained more knowledge and could avoid unnecessary tests through evidence-based medicine. European and Americans have also developed corresponding guidelines for COVID-19. There is much to be learned from the self-renewal and self-improvement practices of medical staff under the COVID-19 pandemic. The process of updating guidelines is not only helpful to global anti-COVID-19 practice but is also valuable for mankind, as we are still facing the threat of pandemics of undiscovered pathogens in the future.

\section{AUTHOR CONTRIBUTIONS}

Z-RC drafted and revised the main body of this paper. YZ modified the content of this paper, JL, H-WP, JZ, H-LZ, L-LL,

\section{REFERENCES}

Agostini, M. L., Andres, E. L., Sims, A. C., Graham, R. L., Sheahan, T. P., Lu, X., et al. (2018). Coronavirus Susceptibility to the Antiviral Remdesivir (GS-5734) Is Mediated by the Viral Polymerase and the Proofreading Exoribonuclease. mBio 9 (2). doi: $10.1128 / \mathrm{mBio} .00221-18$

Al Ghamdi, M., Alghamdi, K. M., Ghandoora, Y., Alzahrani, A., Salah, F., Alsulami, A., et al. (2016). Treatment outcomes for patients with Middle Eastern Respiratory Syndrome Coronavirus (MERS CoV) infection at a coronavirus referral center in the Kingdom of Saudi Arabia. BMC Infect. Dis. 16 (1). doi: 10.1186/s12879-016-1492-4

Alhazzani, W., Møller, M. H., Arabi, Y. M., Loeb, M., Gong, M. N., Fan, E., et al. (2020). Surviving Sepsis Campaign: guidelines on the management of critically ill adults with Coronavirus Disease 2019 (COVID-19). Intensive Care Med. 1. doi: 10.1007/s00134-020-06022-5

Alzghari, S. K., and Acuña, V. S. (2020). Supportive Treatment with Tocilizumab for COVID-19: A Systematic Review. J. Clin. Virol. 127, 104380. doi: 10.1016/ j.jcv.2020.104380

Andreakos, E., and Tsiodras, S. (2020). COVID-19: lambda interferon against viral load and hyperinflammation. EMBO Mol. Med. doi: 10.15252/ emmm.202012465

Antinori, S., Cossu, M. V., Ridolfo, A. L., Rech, R., Bonazzetti, C., and Pagani, G. (2020). Compassionate remdesivir treatment of severe Covid-19 pneumonia in intensive care unit (ICU) and Non-ICU patients: Clinical outcome and differences in post_treatment hospitalisation status. Pharmacol. Res., 104899. doi: 10.1016/j.phrs.2020.104899

Baerenwaldt, A., Biburger, M., and Nimmerjahn, F. (2010). Mechanisms of action of intravenous immunoglobulins. Expert Rev. Clin. Immunol. 6 (3), 425-434. doi: $10.1586 /$ eci.10.9

Beigel, J. H., Tomashek, K. M., Dodd, L. E., Mehta, A. K., Zingman, B. S., Kalil, A. C., et al. (2020). Remdesivir for the Treatment of Covid-19 - Preliminary Report. N. Engl. J. Med. doi: 10.1056/NEJMoa2007764

Bhimraj, A., Morgan, R. L., Shumaker, A. H., Lavergne, V., Baden, L., Cheng, V. C., et al. (2020). Infectious Diseases Society of America Guidelines on the
M-FL, and X-HW helped with drafting and editing. J-HW revised and approved the final version.

\section{FUNDING}

Z-RC received support from Science and Technology Research Project of Department of education of Jiangxi Province (No. GJJ190067).

\section{ACKNOWLEDGMENTS}

The authors thank all the doctors, nurses, pharmacists, and other peers who sacrificed their lives for the discovery, treatment, control, and prevention of COVID-19: Li Wen-liang, Luo Xuan, Mao Xiang-hong, Jiang Ji-jun, Jiang Jin-bo, Liang Wudong, Song Ying-jie, Song Yun-hua, Zhang Jian-hua, Yao Liu-ji, Xu Hui, Wang Tu-cheng, Xiao Jun, Liu Fan, Lin Zhen-bin, Xu De-fu, Chen Jian, Peng Yin-hua, Liu Zhi-ming, Du Xian-sheng, Zhu Zheng-rong, Xia Si-si, Huang Wen-jun, Jiang Xue-qin, Yuan Yang-yang, Zhong Jin-xin, and Mei Zong-ming. The authors thank the Science and Technology Research Project of the Department of Education of Jiangxi Province (No. GJJ190067) for its support.

Treatment and Management of Patients with COVID-19. Clin. Infect. Dis. : Off. Publ. Infect. Dis. Soc. A. doi: 10.1093/cid/ciaa478

Brooks, M. J., Burtseva, E. I., Ellery, P. J., Marsh, G. A., Lew, A. M., Slepushkin, A. N., et al. (2012). Antiviral activity of arbidol, a broad-spectrum drug for use against respiratory viruses, varies according to test conditions. J. Med. Virol. 84 (1), 170181. doi: 10.1002/jmv.22234

Cao, B., Wang, Y., Wen, D., Liu, W., Wang, J., Fan, G., et al. (2020). A Trial of Lopinavir-Ritonavir in Adults Hospitalized with Severe Covid-19. N. Engl. J. Med. 382 (19), 1787-1799. doi: 10.1056/NEJMoa2001282

Chan, K. S., Lai, S. T., Chu, C. M., Tsui, E., Tam, C. Y., Wong, M. M., et al. (2003). Treatment of severe acute respiratory syndrome with lopinavir/ritonavir: a multicentre retrospective matched cohort study. Hong Kong Med. J. 9 (6), 399406. doi: 10.1136/thorax.2003.012658

Chan, J. F., Yao, Y., Yeung, M. L., Deng, W., Bao, L., Jia, L., et al. (2015). Treatment With Lopinavir/Ritonavir or Interferon-betalb Improves Outcome of MERSCoV Infection in a Nonhuman Primate Model of Common Marmoset. J. Infect. Dis. 212 (12), 1904-1913. doi: 10.1093/infdis/jiv392

Chen, C., Zhang, Y., Huang, J., Yin, P., Cheng, Z., Wu, J., et al. (2020). Favipiravir versus Arbidol for COVID-19: A Randomized Clinical Trial. medRxiv. doi: 10.1101/2020.03.17.20037432

Cheng, C., Lee, Y., Chen, C., Lin, Y., Liu, C., Liao, C., et al. (2020). Lopinavir/ ritonavir did not shorten the duration of SARS CoV-2 shedding in patients with mild pneumonia in Taiwan. J. Microbiol. Immunol. Infect. doi: 10.1016/ j.jmii.2020.03.032

China CDC (2020). Tracking the Epidemic. http://weekly.chinacdc.cn/news/ TrackingtheEpidemic.htm [Accessed 2020/05/17 2020].

Chu, C. M., Cheng, V. C., Hung, I. F., Wong, M. M., Chan, K. H., Chan, K. S., et al. (2004). Role of lopinavir/ritonavir in the treatment of SARS: initial virological and clinical findings. Thorax 59 (3), 252-256. doi: 10.1136/thorax.2003.012658

Cutler, D. J., MacIntyre, A. C., and Tett, S. E. (1988). Pharmacokinetics and cellular uptake of 4-aminoquinoline antimalarials. Agents Actions Suppl 24, 142-157. doi: 10.1007/978-3-0348-9160-8_13

Du, D., Song, T., Dai, H., Jing, Z., Chen, P., and Wu, S. (2018). Stereotactic body radiation therapy and thymosin alpha-1-induced anti-tumor effects in heavily 
pretreated, metastatic esophageal squamous cell carcinoma patients. Oncoimmunology 7 (8), e1450128. doi: 10.1080/2162402X.2018.1450128

Fan, Z., Chen, L., Li, J., Tian, C., Zhang, Y., Huang, S., et al. (2020). Clinical Features of COVID-19 Related Liver Damage. medrxiv. doi: 10.1101/ 2020.02.26.20026971. 02.26.20026971.

FDA ACTEMRA. (2020). (tocilizumab) injection. https://www.accessdata.fda.gov/ drugsatfda_docs/label/2017/125276s114lbl.pdf ].

FDA (2020). Emergency Use Authorization. https://www.fda.gov/emergencypreparedness-and-response/mcm-legal-regulatory-and-policy-framework/ emergency-use-authorization\#covidtherapeutics [Accessed 2020.05.17].

Furuta, Y., Komeno, T., and Nakamura, T. (2017). Favipiravir (T-705), a broad spectrum inhibitor of viral RNA polymerase. Proc. Jpn. Acad. Ser. B. Phys. Biol. Sci. 93 (7), 449-463. doi: 10.2183/pjab.93.027

Gao, J., Tian, Z., and Yang, X. (2020). Breakthrough: Chloroquine phosphate has shown apparent efficacy in treatment of COVID-19 associated pneumonia in clinical studies. BioSci. Trends. doi: 10.5582/bst.2020.01047

Gorbalenya, A. E., Baker, S. C., Baric, R. S., de Groot, R. J., Drosten, C., Gulyaeva, A. A., et al. (2020). The species Severe acute respiratory syndrome-related coronavirus: classifying 2019-nCoV and naming it SARS-CoV-2. Nat. Microbiol. doi: 10.1038/s41564-020-0695-z

Grein, J., Ohmagari, N., Shin, D., Diaz, G., Asperges, E., Castagna, A., et al. (2020). Compassionate Use of Remdesivir for Patients with Severe Covid-19. N. Engl. J. Med. doi: 10.1056/NEJMoa2007016

Griffith, J. F., Antonio, G. E., Kumta, S. M., Hui, D. S., Wong, J. K., Joynt, G. M., et al. (2005). Osteonecrosis of hip and knee in patients with severe acute respiratory syndrome treated with steroids. Radiology 235 (1), 168-175. doi: 10.1148/radiol.2351040100

Haagmans, B. L., Kuiken, T., Martina, B. E., Fouchier, R. A., Rimmelzwaan, G. F., van Amerongen, G., et al. (2004). Pegylated interferon-alpha protects type 1 pneumocytes against SARS coronavirus infection in macaques. Nat. Med. 10 (3), 290-293. doi: 10.1038/nm1001

Hidalgo-Cantabrana, C., Delgado, S., Ruiz, L., Ruas-Madiedo, P., Sanchez, B., and Margolles, A. (2017). Bifidobacteria and Their Health-Promoting Effects. Microbiol. Spectr. 5 (3). doi: 10.1128/microbiolspec.BAD-0010-2016

Hoffmann, M., Kleine-Weber, H., Schroeder, S., Kruger, N., Herrler, T., Erichsen, S., et al. (2020). SARS-CoV-2 Cell Entry Depends on ACE2 and TMPRSS2 and Is Blocked by a Clinically Proven Protease Inhibitor. Cell. doi: 10.1016/ j.cell.2020.02.052

Holshue, M. L., DeBolt, C., Lindquist, S., Lofy, K. H., Wiesman, J., Bruce, H., et al. (2020). First Case of 2019 Novel Coronavirus in the United States. N. Engl. J. Med. doi: 10.1056/NEJMoa2001191

Hong, X., Currier, G. W., Zhao, X., Jiang, Y., Zhou, W., and Wei, J. (2009). Posttraumatic stress disorder in convalescent severe acute respiratory syndrome patients: a 4-year follow-up study. Gen. Hosp. Psychiatry 31 (6), 546-554. doi: 10.1016/j.genhosppsych.2009.06.008

Hulseberg, C. E., Feneant, L., Szymanska-de, W. K., Kessler, N. P., Nelson, E. A., Shoemaker, C. J., et al. (2019). Arbidol and Other Low-Molecular-Weight Drugs That Inhibit Lassa and Ebola Viruses. J. Virol. 93 (8). doi: 10.1128/ JVI.02185-18

Hung, I. F., Lung, K., Tso, E. Y., Liu, R., Chung, T. W., Chu, M., et al. (2020). Triple combination of interferon beta- $1 \mathrm{~b}$, lopinavir-ritonavir, and ribavirin in the treatment of patients admitted to hospital with COVID-19: an open-label, randomised, phase 2 trial. Lancet. doi: 10.1016/S0140-6736(20)31042-4

Italian Society of Infectious and Tropical Diseases SECTION. (2020). Handbook for the care of people with disease-COVID-19 (Edition 2.0).

Jin, Y. H., Cai, L., Cheng, Z. S., Cheng, H., Deng, T., Fan, Y. P., et al. (2020). A rapid advice guideline for the diagnosis and treatment of 2019 novel coronaviru-nCoV) infected pneumonia (standard version). Mil. Med. Res. 7 (1), 4. doi: 10.1186/s40779-020-0233-6

Jun, C., Yun, L., Xiuhong, X., Ping, L., Feng, L., Tao, L., et al. (2020). Efficacies of lopinavir/ritonavir and abidol in the treatment of novel coronavirus pneumonia. Chin. J. Infective Dis. 38 (00), E8. doi: 10.3760/cma.j.issn.10006680.2020 .02 .006

Kadam, R. U., and Wilson, I. A. (2017). Structural basis of influenza virus fusion inhibition by the antiviral drug Arbidol. Proc. Natl. Acad. Sci. U. S. A. 114 (2), 206-214. doi: 10.1073/pnas.1617020114

Kakuda, T. N., Crauwels, H., Opsomer, M., Tomaka, F., van de Casteele, T., Vanveggel, S., et al. (2015). Darunavir/cobicistat once daily for the treatment of
HIV. Expert Rev. Anti. Infect. Ther. 13 (6), 691-704. doi: 10.1586/ 14787210.2015.1033400

Khamitov, R. A., Loginova, S., Shchukina, V. N., Borisevich, S. V., Maksimov, V. A., and Shuster, A. M. (2008). [Antiviral activity of arbidol and its derivatives against the pathogen of severe acute respiratory syndrome in the cell cultures]. Vopr. Virusol. 53 (4), 9-13.

Kim, J. Y. (2020). Letter to the Editor: Case of the Index Patient Who Caused Tertiary Transmission of Coronavirus Disease 2019 in Korea: the Application of Lopinavir/Ritonavir for the Treatment of COVID-19 Pneumonia Monitored by Quantitative RT-PCR. J. Korean Med. Sci. 35 (7), e88. doi: 10.3346/ jkms.2020.35.e88

Kluge, S., Janssens, U., Welte, T., Weber-Carstens, S., Marx, G., and Karagiannidis, C. (2020). German recommendations for critically ill patients with COVID-19. Medizinische Klinik - Intensivmedizin und Notfallmedizin 115 (3), 175-177. doi: 10.1007/s00063-020-00674-3

Le, R. Q., Li, L., Yuan, W., Shord, S. S., Nie, L., Habtemariam, B. A., et al. (2018). FDA Approval Summary: Tocilizumab for Treatment of Chimeric Antigen Receptor T Cell-Induced Severe or Life-Threatening Cytokine Release Syndrome. Oncologist 23 (8), 943-947. doi: 10.1634/theoncologist.2018-0028

Li, C., Zhu, X., Ji, X., Quanquin, N., Deng, Y. Q., Tian, M., et al. (2017). Chloroquine, a FDA-approved Drug, Prevents Zika Virus Infection and its Associated Congenital Microcephaly in Mice. EBioMedicine 24, 189-194. doi: 10.1016/j.ebiom.2017.09.034

Lian, N., Xie, H., Lin, S., Huang, J., Zhao, J., and Lin, Q. (2020). Umifenovir treatment is not associated with improved outcomes in patients with coronavirus disease 2019: a retrospective study. Clin. Microbiol. Infect. doi: 10.1016/j.cmi.2020.04.026

Lim, J., Jeon, S., Shin, H. Y., Kim, M. J., Seong, Y. M., Lee, W. J., et al. (2020). Case of the Index Patient Who Caused Tertiary Transmission of COVID-19 Infection in Korea: the Application of Lopinavir/Ritonavir for the Treatment of COVID-19 Infected Pneumonia Monitored by Quantitative RT-PCR. J. Korean Med. Sci. 35 (6), e79. doi: 10.3346/jkms.2020.35.e79

Liu, Y., Gayle, A. A., Wilder-Smith, A., and Rocklov, J. (2020). The reproductive number of COVID-19 is higher compared to SARS coronavirus. J. Travel Med. doi: $10.1093 / \mathrm{jtm} / \mathrm{taaa} 021$

Lou, Y., Liu, L., and Qiu, Y. (2020). Clinical Outcomes and Plasma Concentrations of Baloxavir Marboxil and Favipiravir in COVID-19 Patients: an Exploratory Randomized, Controlled Trial. medRxiv. doi: 10.1101/2020.04.29.20085761

Loutfy, M. R., Blatt, L. M., Siminovitch, K. A., Ward, S., Wolff, B., Lho, H., et al. (2003). Interferon alfacon-1 plus corticosteroids in severe acute respiratory syndrome: a preliminary study. JAMA 290 (24), 3222-3228. doi: 10.1001/ jama.290.24.3222

Mahase, E. (2020). Covid-19: Remdesivir is helpful but not a wonder drug, say researchers. BMJ, m1798. doi: 10.1136/bmj.m1798

Mangum, E. M., and Graham, K. K. (2001). Lopinavir-Ritonavir: a new protease inhibitor. Pharmacotherapy 21 (11), 1352-1363. doi: 10.1592/phco.21.17. 1352.34419

Mehra, M. R., Desai, S. S., Ruschitzka, F., and Patel, A. N. (2020). Hydroxychloroquine or chloroquine with or without a macrolide for treatment of COVID-19: a multinational registry analysis. Lancet. doi: 10.1016/S0140-6736(20)31180-6

Mingxing Huang, M. L. F. X., Li, Y., Tang, M., Zhou, J., Jiang, G., Xiang, J., et al. (2020). Preliminary evidence from a multicenter prospective observational study of the safety and efficacy of chloroquine for the treatment of COVID-19. Natl. Sci. Rev., nwaal13. (pre-print). doi: 10.1093/nsr/nwaal13

National Public Radio (2020). Coronavirus: COVID-19 Is Now Officially A Pandemic, WHO Says. https://www.npr.org/sections/goatsandsoda/2020/03/ 11/814474930/coronavirus-covid-19-is-now-officially-a-pandemic-who-says [Accessed 2020/05/17 2020].

NIH (2020). Coronavirus Disease 2019 (COVID-19) Treatment Guidelines. https:// www.covid19treatmentguidelines.nih.gov/whats-new/ [Accessed 2020/05/17].

Prokunina-Olsson, L., Alphonse, N., Dickenson, R. E., Durbin, J. E., Glenn, J. S., Hartmann, R., et al. (2020). COVID-19 and emerging viral infections: The case for interferon lambda. J. Exp. Med. 217 (5). doi: 10.1084/jem.20200653

Qaseem, A., Yost, J., Etxeandia-Ikobaltzeta, I., Miller, M. C., Abraham, G. M., Obley, A. J., et al. (2020). Should Clinicians Use Chloroquine or Hydroxychloroquine Alone or in Combination With Azithromycin for the Prophylaxis or Treatment of COVID-19? Ann. Intern. Med. doi: 10.7326/M20-1998 
Riou, B., Barriot, P., Rimailho, A., and Baud, F. J. (1988). Treatment of severe chloroquine poisoning. N. Engl. J. Med. 318 (1), 1-6. doi: 10.1056/ NEJM198801073180101

Riva, A., Conti, F., Bernacchia, D., Pezzati, L., Sollima, S., Merli, S., et al. (2020). Darunavir does not prevent SARS-CoV-2 infection in HIV patients. Pharmacol. Res. 157, 104826. doi: 10.1016/j.phrs.2020.104826

Savarino, A., Boelaert, J. R., Cassone, A., Majori, G., and Cauda, R. (2003). Effects of chloroquine on viral infections: an old drug against today's diseases? Lancet Infect. Dis. 3 (11), 722-727. doi: 10.1016/s1473-3099(03)00806-5

Shanghai Clinical Treatment Expert Group for corona virus disease 2019 (2020). Comprehensive treatment and management of corona virus disease 2019: expert consensus statement from Shanghai. Chin. J. Infective Dis. 38 (Epub ahead of print.). doi: 10.3760/cma.j.issn.1000-6680.2020.03.002

Sheahan, T. P., Sims, A. C., Leist, S. R., Schafer, A., Won, J., Brown, A. J., et al. (2020). Comparative therapeutic efficacy of remdesivir and combination lopinavir, ritonavir, and interferon beta against MERS-CoV. Nat. Commun. 11 (1), 222. doi: 10.1038/s41467-019-13940-6

Tang, W., Cao, Z., Han, M., Wang, Z., Chen, J., Sun, W., et al. (2020). Hydroxychloroquine in patients with mainly mild to moderate coronavirus disease 2019: open label, randomised controlled trial. BMJ, m1849. doi: 10.1136/ bmj.m1849

Te, H. S., Randall, G., and Jensen, D. M. (2007). Mechanism of action of ribavirin in the treatment of chronic hepatitis C. Gastroenterol. Hepatol. (N. Y.) 3 (3), 218-225.

The national commission of the people's republic of China (2020a). Guideline for the diagnosis and treatment of serious and critical 2019 novel coronavirus (2019-nCoV) infected pneumonia (trial edition 1). http://med.china.com.cn/ content/pid/156973/tid/1026 [Accessed 2020/05/17].

The national commission of the people's republic of China (2020b). Guideline for the diagnosis and treatment of 2019 novel coronavirus (2019-nCoV) infected pneumonia (trial edition 2). https://mp.weixin.qq.com/s/86s1xhapo3ILEmuzbIzXaw [Accessed 2020/05/17].

The national commission of the people's republic of China (2020c). Guideline for the diagnosis and treatment of 2019 novel coronavirus (2019- $n \mathrm{CoV}$ ) infected pneumonia (trial edition 3). http://www.nhc.gov.cn/yzygj/s7653p/202001/ f492c9153ea9437bb587ce2ffcbee1fa/files/39e7578d85964dbe81117736dd789d8f. pdf. [Accessed 2020/05/17].

The national commission of the people's republic of China (2020d). Guideline for the diagnosis and treatment of 2019 novel coronavirus (2019-nCoV) infected pneumonia (trial edition 4). http://www.nhc.gov.cn/yzygj/s7653p/202001/ 4294563ed35b43209b31739bd0785e67/files/7a9309111267475a99d4306962c8bf78. pdf. [Accessed 2020/05/17].

The national commission of the people's republic of China (2020e). Guideline for the diagnosis and treatment of 2019 novel coronavirus (2019-nCoV) infected pneumonia (trial edition 5). http://www.nhc.gov.cn/yzygj/s7653p/202002/ 3b09b894ac9b4204a79db5b8912d4440/files/7260301a393845fc87fcf6dd52965ecb. pdf. [Accessed 2020/05/17].

The national commission of the people's republic of China (2020f). Guideline for the diagnosis and treatment of 2019 novel coronavirus (2019- $n \mathrm{CoV}$ ) infected pneumonia (trial edition 6). http://www.nhc.gov.cn/yzygj/s7653p/202002/ 8334a8326dd94d329df351d7da8aefc2/files/b218cfeb1bc54639af227f922bf6b817. pdf. [Accessed 2020/05/17].

The national commission of the people's republic of China (2020g). Guideline for the diagnosis and treatment of 2019 novel coronavirus (2019-nCoV) infected pneumonia (trial edition 7). p.11-21. http://www.nhc.gov.cn/yzygj/s7653p/202001/ ccee6ec0942a42a18df8e5ce6329b6f5/files/0b87e4df3e4f4289af21061b248fd1e6.pdf. [Accessed 2020/05/17].

The national commission of the people's republic of China (2020h). Guideline for the diagnosis and treatment of serious and critical 2019 novel coronavirus
(2019-nCoV) infected pneumonia (trial edition 1). https://mp.weixin.qq.com/s/ kbA6ZxZcA9wT2Sz44YGYWw [Accessed 2020/05/17].

The national commission of the people's republic of China (2020i). Guideline for the diagnosis and treatment of serious and critical 2019 novel coronavirus (2019- $n$ CoV) infected pneumonia (trial edition 2). https://mp.weixin.qq.com/s/ FtG2Z5ZkaqYL77Zqtb_ipQ [Accessed 2020/05/17].

Wang, M., Cao, R., Zhang, L., Yang, X., Liu, J., Xu, M., et al. (2020). Remdesivir and chloroquine effectively inhibit the recently emerged novel coronavirus, (2019$\mathrm{nCoV}$ ) in vitro. Cell Res. 30 (3), 269-271. doi: 10.1038/s41422-020-0282-0

Wang, Y., Zhang, D., Du, G., Du, R., Zhao, J., Jin, Y., et al. (2020). Remdesivir in adults with severe COVID-19: a randomised, double-blind, placebo-controlled, multicentre trial. Lancet 395 (10236), 1569-1578. doi: 10.1016/S0140-6736(20) 31022-9

Wang, Z., Chen, X., Lu, Y., Chen, F., and Zhang, W. (2020). Clinical characteristics and therapeutic procedure for four cases with 2019 novel coronavirus pneumonia receiving combined Chinese and Western medicine treatment. Biosci. Trends. doi: 10.5582/bst.2020.01030

Warren, T. K., Jordan, R., Lo, M. K., Ray, A. S., Mackman, R. L., Soloveva, V., et al. (2016). Therapeutic efficacy of the small molecule GS-5734 against Ebola virus in rhesus monkeys. Nature 531 (7594), 381-385. doi: 10.1038/nature17180

WHO, W. H. O. (2020a). Coronavirus disease (COVID-2019) situation reports. https://www.who.int/emergencies/diseases/novel-coronavirus-2019/situationreports/ [Accessed 2020/05/17].

WHO, W. H. O. (2020b). 2019- $n$ CoV outbreak is an emergency of international concern. http://www.euro.who.int/en/health-topics/health-emergencies/ coronavirus-covid-19/news/news/2020/01/2019-ncov-outbreak-is-anemergency-of-international-concern [Accessed 2020/05/17 2020].

Wilson, K. C., Chotirmall, S. H., Bai, C., and Rello, J. (2020). COVID-19: Interim Guidance on Management Pending Empirical. From an American Thoracic Society-led International Task Force. https://www.thoracic.org/covid/covid-19guidance.pdf [Accessed 2020/05/17].

Wu, J. Z., Lin, C. C., and Hong, Z. (2003). Ribavirin, viramidine and adenosinedeaminase-catalysed drug activation: implication for nucleoside prodrug design. J. Antimicrob. Chemother. 52 (4), 543-546. doi: 10.1093/jac/dkg405

Xu, X., Han, M., Li, T., Sun, W., Wang, D., Fu, B., et al. (2020). Effective treatment of severe COVID-19 patients with tocilizumab. Proc. Natl. Acad. Sci. U. S. A. 117 (20), 10970-10975. doi: 10.1073/pnas.2005615117

Xu, Z., Shi, L., Wang, Y., Zhang, J., Huang, L., Zhang, C., et al. (2020). Pathological findings of COVID-19 associated with acute respiratory distress syndrome. Lancet Respir. Med. doi: 10.1016/S2213-2600(20)30076-X

Zeng, L. Y., Yang, J., and Liu, S. (2017). Investigational hemagglutinin-targeted influenza virus inhibitors. Expert Opin. Invest. Drugs 26 (1), 63-73. doi: 10.1080/13543784.2017.1269170

Zumla, A., Chan, J. F. W., Azhar, E. I., Hui, D. S. C., and Yuen, K. (2016). Coronaviruses - drug discovery and therapeutic options. Nat. Rev. Drug Discovery 15 (5), 327-347. doi: 10.1038/nrd.2015.37

Conflict of Interest: The authors declare that the research was conducted in the absence of any commercial or financial relationships that could be construed as a potential conflict of interest.

Copyright (C) 2020 Chen, Zhou, Liu, Peng, Zhou, Zhong, Liu, Lai, Wei and Wen. This is an open-access article distributed under the terms of the Creative Commons Attribution License (CC BY). The use, distribution or reproduction in other forums is permitted, provided the original author(s) and the copyright owner(s) are credited and that the original publication in this journal is cited, in accordance with accepted academic practice. No use, distribution or reproduction is permitted which does not comply with these terms. 